thoroughfares; public baths; the conditions governing the application of syphon traps to the interior of inhabited $d$ wellings ; the disposition of rooms in dwellings ; the necessity of an effective control of the sanitary services in private dwellings ; the rational warming of dwellings ; the professional teaching of hygiene; and the unification of methods employed in drawing up sanitary statistics. The latter subject will be treated by Dr. J. Bertillon, Chief of the Paris Statistical Department. On most of these questions printed reports will be distributed to the members before the Congress meets, and these reports will be discussed at the morning sittings. In the afternoons private members may introduce other questions for discussion. This Congress will, in conjunction with the Exhibition, have the advantage of lifting sanitary questions out of the domain of mere theory, and of compelling everyone to face and study the difficalties of practical application. As an ounce of practice is worth a pound of theory the Exhibition and Congress should be well supported.

\section{A MATTER OF ETIQUETTE.}

We publish below what we may hope is the final correspondence in a matter to which we have previously referred upon several occasions-namely, the relations between the Vestry of St. George's, Southwark, and Dr. Waldo, their medical officer of health. To recapitulate shortly, the Vestry demanded of Dr. Waldo that he should revise other medical men's certificates, unknown to them, for they were not always satisfied with the certificates submitted. Dr. Waldo refused absolutely to commit such a breach of medical etiquette. He appealed to the Local Government Board, and the Board has decided that he is right. We congratulate Dr. Waldo on the stand he has made for courtesy and righteous dealing. Now the case of the School Board and its discourteous resolution of May 30 th stands on exactly the same footing. The School Board has appointed medical men to revise other medical men's certificates, presumably unknown to the original authors of the certificates, and at the bidding, moreover, of the divisional superintendent, a layman. It is to be hoped that the Education Department will convey to the Board an opinion that the Board have acted in, to say the least of it, an impolitic manner. The question, we suppose, will come up at the forthcoming meeting of the Board, and if the Board is wise it will rescind a resolation which ought never even to have been submitted. The following is the correspondence allnded to abore :-

$$
\text { St. George-the-Martyr, Southwark, }
$$

Vestry Hall, Borough-road,

To the Secretary, Local Government Board. May 23rd, 1895.

Dear SIR, - I am desired by the Vestry of St. George-theMartyr, Southwark, to ask the advice and guidance of your Board in the following difficulty:-

When Dr. Waldo was appointed medical officer in the year 1892 he signed the enclosed list of regulations, and in accordance with Regulation No. 19 he bound himself to visit pro. fessionally the employés of the Vestry when sick, as the Vestry allow sick pay, and they are not always satisfied with the medical certificates submitted, for they fear that malingering is not unknown. In carrying out this regulation, Dr. Waldo finds himself in a position of difficulty. If he calls on any employé without communication with the medical attendant who gave the certificate, he informs the Vestry that he will be guilty of a serious breach of medical etiquette, and if he gives notice to the employés medical attendant and arranges a formal consultation the Vestry feel that the value of such visit will be lost, and they will be involved in considerable expense.

If Dr. Waldo finds himself obliged to report to the Vestry that the certificate of the medical attendant was not justified by the patient's condition, his relations with the local medical men will become strained and his work as medical officer of health suffer. Some members of this Vestry, on the other hand, are of opinion that the Post Office, the large supply associations, and some large friendly societies, require that visits (with the object of detecting malingering) should be paid by their own officers. They see no reason why Dr. Waldo should not accordingly fulfil the terms of his engagement, without prejudice to his status in the medical world and without offence to medical etiquette. Yours faithfully,

\section{(Signed) A. MillaR, Vestry Clerk.}

Local Government Board, Whitehall, S.W., June 12th, 1895.

SIR, - I am directed by the Local Government Board to acknowledge the receipt of your letter of the $23 \mathrm{rd}$ ult., relative to the duty undertaken by Dr. F. J. Waldo, the medical officer of health for the parish of St. George-the-Martyr, Southwark, "to attend, if required, the flushers and sewers men and other employés of the Vestry during illness," and requesting the Board's advice and guidance in the difficulty which has arisen in regard thereto. The Board have carefully considered the representations on the subject submitted in your letter and in the report of Dr. Waldo which accompanied it.

On the general question the Board would observe that as regards duties of a somewhat analogous character which at times devolve on the medical officer of health under the Infections Disease (Notification) Act, they have laid it down that even when question arises as to the good faith of a certifying medical practitioner the medical officer of health should, if it becomes necessary to revise a certificate, not only seek the coöperation of the medical practitioner concerned, but should also observe, as far as possible, the customs that usually govern the relations of medical practitioners to each other. On the particular case submitted in your letter of the $23 \mathrm{rd}$ ult. the Board do not gather that the undertaking entered into by Dr. Waldo "to attend if required" on certain employés "during illness" involves any obligation on his part to revise either the diagnosis or the certificates granted by othey medical practitioners who have been called in to attend on such persons. I am, Sir, your obecient servant,

A Millar, Esq., Vestry Clerk, Borough-road, S.E. Assistant Secretary.

\section{THE ASSOCIATION OF FELLOWS OF THE ROYAL COLLEGE OF SURGEONS OF ENGLAND.}

A MAETING of the committee of the Association of Fellows of the Royal College of Surgeons of England was held at 101, Harley.street, at 530 P.M., on Jane 26th. Mr. T. Holmes, one of the Vice-Presidents, occupied the chair, in the nnavoidable absence of the President, $\mathbf{M r}$. George Pollock, and there was a large attendance of mem. bers of the committee. The minutes of the last meeting of the committee were read and confirmed. The honorary secretary, Mr. Percy Dunn, reported that he had daly issued the circular-letter addressed to the Fellows adopted at the previous meeting of the committee. He then read letters from five Fellows of the College desirous of being elected as Members of the Association. These were proposed and seconded by members of the committee and unanimously elected.

The honorary secretary reported the proceedings at the deputation to the committee of the Council which took place on the 10th inst., as already reported in THE LANCET of June 15th. In reference to this matter the honorary secretary reported that the deputation had been asked by the committee of Council to draw up a préois of the arguments adduced in favour of their propositions for amending the charters and by-laws, and that the subcommittee appointed by the committee of the Association at a recent meeting had already commenced this précis and now submitted it to the committee. After some discussion, the committee approved generally of the work of the subcommittee, and requested them to complete it as ioon as possible.

A resolution was proposed, seconded, and unanimously passed, expressing the hope that all the members of the Association would record their votes in favour of Mr. Willett, Mr. Norton, and Dr. Ward Cousins.

With respect to the annual general meeting of the Association it was decided that the date should be fixed by the committee after the election at the College on the 4th prox.

This concluded the business of the meeting, and the com. mittee adjourned. 